\title{
INTEGRAL ACTION OF METARHIZIUM ANISOPLIAE VAR. ACRIDUN AND LOW DOSE OF SOME AFFECTING TREATMENTS AGAINST LOCUSTA MIGRATORIA MIGRATORIOIDES UNDER FIELD CONDITIONS \\ Ali, T. A. A. and G. A. Mohamed \\ Locust and Grasshoppers Res. Section, Plant Prot. Res. Inst., A.R.C. Dokki, Giza, Egypt.
}

\begin{abstract}
The effect of Metarhizium anisopliae var. acridum, anti-feedant agent (azadirachtin), anti-molting agent (Flufenoxuron), Juvenile hormone analogue compound (pyripoxyfen) and Chloropyrifos (two formulations) was evaluated under field conditions of Shark El-Uwainat area against the nymphal instars $3^{\text {rd }}, 4^{\text {th }}$ and $5^{\text {th }}$ of Locusta migratoria migratorioides. The obtained results revealed that the integration between $M$. anisopliae and $20 \%$ of the recommended dose of all the compounds exhibited the highest integral action, recording $100 \%$ population reduction after (1113days) of application. On the other hand, the fungus alone induced moderate percentages of population reduction after 10 days of treatment.

Also, on comparing the dose and half the dose of the fungus the full dose gave approximately the same trend of activity. Green muscle ( $M$. anisopliae), antifeedant agent, anti-molting agent and juvenile hormone analogues compound can be useful for proposed different elements of an IPM strategy.
\end{abstract}

\section{INTRODUCTION}

The locusts, Schistocerca gregaria and Locusta migratoria migratorioides are considered the most economic important pests in Shark El-Uwainat area in the Western desert of Egypt. The existing control methods against these pests still rely on chemical insecticides which are not always appropriate. Looking for an alternative favorable and environmentally acceptable control methods against these pests, Prior and Greathed (1989) stated that the use of pathogens may offer this safety control measures, Goettel, et al. (1995) added that hyphomycete fungi are not pathogenic to non target organisms. The Deuteromycete pathogenic fungus, $M$. anisopliae promise to be a biocontrol agent against locust (Lomer,1997) and (Arthurs\& Thomas, 2000). M. anisopliae caused a reduction in the feeding activity and induced a significant mortality percentage in the nymphal instars of locust (Arthurs and Thomas, 2000)

According to Abdel-Fattah (2005) the sub-lethal doses of insecticides are not toxic to the fungus $M$. anisopliae var. acridum Isolate IMI 330189 and did not inhibit its effect on locust $S$. gregaria. Fungus $M$. anisopliae var. acridum approved to be a specific bio-pesticide for controlling Acrididae pests but it seems to be slow acting as a bio-agent unlike chemical pesticides (Hosny, et al., 2009). The integration between M. anisopliae and $25 \%$ of the recommended dose of Chlorfluazurone (Atabrone $5 \%$ ) exhibited the highest integrated action, recording $60 \%$ population reduction after 
10days of application and $100 \%$ after 19days post treatment to nymphal instars $3^{\text {rd }}, 4^{\text {th }}$ and $5^{\text {th }}$ of the berseem grasshopper, Euprepocnemis plorans plorans (Abdel-Fattah, et al., 2012). The present study deals with the investigation of the most potent integrated action of $M$. anisopliae var. acridum, an anti-feedant agent, azadirachtin, an anti-molting compound, cascade $10 \%$ E.C., juvenile hormone analogues compound, Admiral $10 \%$ E.C. and Chloropyrifos (two formulations) against the African locust, $L$. migratoria migratorioides in Shark El-Uwainat area in the Western desert of Egypt.

\section{MATERIALS AND METHODS}

Ecological surveys were carried out in summer (season 2010) to evaluate the major insect pest of Acrididae prevailing in Shark El-Uwainat area. The results indicated that, the African locust, Locusta migratoria migratorioides was the most important insect pest in this area especially, on clover, maize and cereal crops. The prevailing other Acrididae were, $S$. gregaria, Heteracris annulosa and Acrotylus insubricus. Thus the African locust was chosen to evaluate the most potent integrated action of the proposed chemicals and the microbial pathogen during the summer season of 2010.

\section{Pathogen and tested chemicals:}

1-Fungus (green muscle) was used at 2 rates of application $25 \mathrm{~g}$ and $50 \mathrm{~g} / \mathrm{ha}$.

2-The anti-feeding agent used was Neem RAJ 90\% E.C. produced by Northern Minerals LTd., India. It was used by rate $1 \mathrm{~L} /$ Feddan.

3-The anti-molting agent used was cascade (Tufenoxuron) 10\% E.C. by rate 1 L./ Feddan.

4-Juvenile hormone analogue compound, Admiral (Pyriproxyfine) 10\% E.C. by rate $1 \mathrm{~L} /$ Feedan

5-Chloropyrifos (pestban $48 \%$ E.C.) 1 L/ ha.

6-Chloropyrifos (45\% U.L.V.) 1/2L/ha.

\section{Experimental design:}

The experimental field (heavily infested with $3^{\text {rd }}, 4^{\text {th }}$ and $5^{\text {th }}$ nymphal instar of $L$. migratoria migratorioides more than $20 \mathrm{nymphs} / \mathrm{m}^{2}$ ) was divided into plots of about, $(35 \times 20)=700 \mathrm{~m} 2$ with a wide belt of $10 \times 25=250 \mathrm{~m}^{2}$ to prevent immigration of treated nymphs to other plots and avoid the drift of spray. Plots laying up wind of treatments were used for the control and sprayed with water, sunflower oil and diesel oil as carrier. $20 \%$ dose of one treatment was prepared in a sprayer and half the dose of the fungus also prepared in another sparyer. Firstly, the $20 \%$ of the dose of a treatment was sprayed on the plot and after finishing, immediately, half the dose of the fungus was sprayed on the same plot. This was repeated with the complete dose of the fungus. This technique was carried out according to El-Gammal et al. (2004). Each treatment was represented with five replicates of cages $(0.5 \times 0.5 \times 0.5 \mathrm{~m})$ each. The insects were collected randomly from each treatment directly after application by using sweep net and placed in the cages. The cages were maintained on the area of treatment under the field conditions and provided with treated plants for the treated insects. Daily each 
cage conformed so nymphs. Mortality counts were recorded daily until the $20^{\mathrm{th}}$ day post treatment. The insects were considered dead when they were unable to right themselves after being turned upside down. Insects that died during the bioassay were washed by water, sterilized by using ethanol $70 \%$ and placed in Petri-dishes on damp tissue paper. Dead locusts due to the pathogen were recorded only if the entomopathogen developed on the cadavers.

Application equipment:

- Sprayer: the ULVA+

- Nozzle: Red nozzle was used in all treatments and calibrated $90 \mathrm{ml}$

water $/ \mathrm{min}$ and $60 \mathrm{ml}$ diesel oil $/ \mathrm{min}$.

- spraying height: $0.5 \mathrm{~m}$ above the plants

- Walking speed: $40 \mathrm{~m} / \mathrm{min} .=2.4 \mathrm{~km} / \mathrm{hr}$.

- Swath width: $3 \mathrm{~m}$ according to wind velocity

- Wind: 4-6 m/sec. measured by (anemometery)

- Humidity $(\mathrm{RH}): 50-60 \%$ measured by psychrometer.

- Temperature: was $35 \pm 2 \stackrel{\circ}{ } \mathrm{C}$

- The sun rose: clearly

- The spraying was done between 8 and 11 am in the morning

Assessments:

In the cages, routine work was carried out daily includes removing the previous uneaten food, faeces, dead nymphs and counting the living insects before introducing the fresh food. Mortality data were summarized as estimates of the median lethal time (MLT). 1995)

Data were analyzed using general linear model procedures (SAS,

\section{RESULTS AND DISCUSSION}

The effectiveness of the fungus Metarhizium anisopliae var. acridum, the anti-feeding agent, azadirachtin, the anti-molting compound, cascade $10 \%$ E.C., juvenile hormone analogue compound, Admiral 10\% E.C. and Chloropyrifos(two formulations) was evaluated under field conditions: against $3^{\text {rd }}, 4^{\text {th }}$ and $5^{\text {th }}$ nymphal instars of African locust, L. migratoria migratorioides. Mortality data were summarized as estimates of the median lethal time (MLT), which was calculated as a number of days to achieve an accumulated $50 \%$ mortality using a linear interpolation of corrected daily mortalities.

As show in Table (1) the obtained data indicates that mortalities of the African locust nymphs occurred after 4 days of treatment with the fungus, $M$. anisopliae var. acridum alone. These mortalities percentages were 10 and 8 after 5 days, 50 and 42 after 10 days, 88,80 after 15 days and 98,95 after 20 days to $50 \mathrm{~g} / \mathrm{ha}$. and $25 \mathrm{~g} / \mathrm{ha}$, respectively. In treatments of anti-feeding agent alone mortalities appeared after 2 days. These mortality percentages were 25 after 5 days, 65 after 10 days and 99 after 19 days. The treatment of Flufenoxuron spray alone, mortality percentages were 30,54, 75 and 95 after $5,10,15$ and 20 days, respectively. Mortality percentages of pyripoxyfen alone were 30, 56, 78and 97 after 5, 10, 15 and 20 days, respectively. While mortality percentages were 100,100 and 99 after 5days to pestban, 
Chloropyrifos +diesel oil and Chloropyrifos + sunflower oil respectively. Abdel-Fattah (2005) showed that the use of the fungus, M. anisopliae var. acridum alone for controlling the desert locust, $S$. gregaria in the field, caused a mortality percentage of $98.8 \%$ after 16 days. Gesraha (2007) revealed that commercially formulated entomopathogenic fungi, Bioranza (Metarhizium anisopliae) and Biovar (Beauveria bassiana) were evaluated against the desert locust, $S$. gregaria.

Table (1): Effect of the fungus, Metarhizium anisopliae var. acridum and some affecting treatments against nymphs of the African locust, L. migratoria migratorioides in the field.

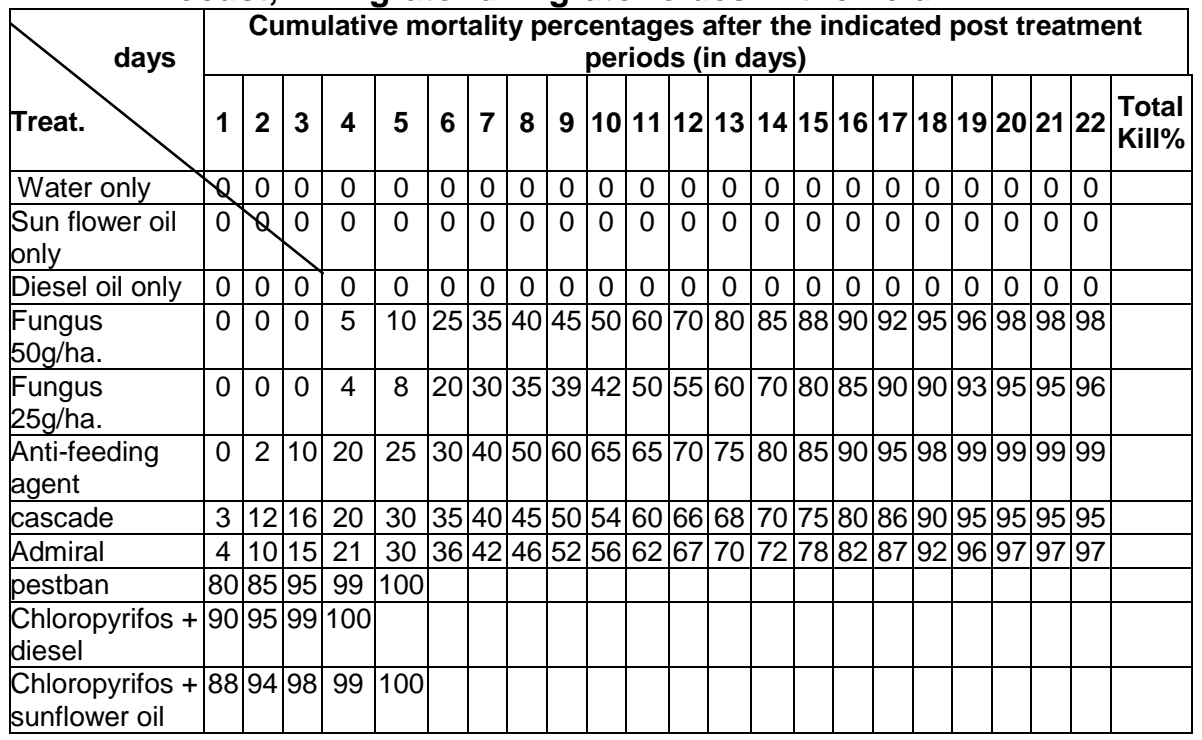

Results clarified that $M$. anisopliae induced significant higher rapid effects than $B$. bassiana on the pest. More than $95 \%$ mortality was achieved after 10, 12 and 18 days for $M$. anisopliae and after 10,18 and 22 days for $B$. bassiana at 4, 2 and 1 g/L concentrations, respectively. Hosny, et al. (2009) investigated that at field application rates, $50 \mathrm{~g} / \mathrm{ha}$. Dose (diluted in diesel oil) of $M$. anisopliae var. acridum resulted in an optimal mortality of locusts and grasshoppers in the cages during 21 days, followed by $50 \mathrm{~g} / \mathrm{ha}$. dose diluted in vegetable oil. Al-Fifi (2009) tested various Neem products against resting and flying $S$. gregaria the treatment during flight activity caused, for all products applied an increase of the mortality rate, except the Neem oil enriched and pure Neem oil of Giessen, up to 70 and $90 \%$ respectively. Ghazawy, et al. (2010) concluded that after suitable field trials, the use of azadirachtin may be a viable alternative to chemical insecticides for control of grasshoppers in Egypt. Abdel-Fattah, et al. (2012) revealed that the fungus $M$. anisopliae var. acridum treatment was more effective than Chlorfluazurone and Nosema locustae when tested separately against the nymphal instars $3^{\text {rd }}, 4^{\text {th }}$ and $5^{\text {th }}$ of the berseem grasshopper, E. plorans plorans. Also, the fungus alone induced moderate percentages of reduction in the population of 
this pest after 11 days post treatment. Chlorfluazurone spray was more potent than Chlorfluazurone bait.

Data presented in Table (2) illustrate, the integral action of the tested agent (fungus $25 \mathrm{~g} / \mathrm{ha}$. and $20 \%$ of the recommended dose of anti-feeding agent, Flufenoxuron, pyripoxyfen, pestban and Chloropyrifos. The mortality percentages of African locust nymphs caused by the fungus with $20 \%$ of antifeeding agent were 20,80 and $100 \%$ after 5,10 and 13 days of application. El-Gammal, et al. (2004) investigated the integral action of $M$. flavoviride, anti-molting (consult) and anti-feeding agent (Azadirachtin) in a field of shark el-Uwainat area against the last instar nymphs of $L$. migratoria migratorioides. They found that, the integration between fungus and the recommended dose of consult (37.8 g.a.i./fed.) was the most effective treatment inducing $67.2 \%$ population reduction after 5 days of application and $96.8 \%$ after 15 days. The mortality percentages caused by fungus with $20 \%$ of the recommended dose of Flufenoxuron and pyripoxyfen were (15, 75 and 100\%) and (19, 80 and $98 \%$ ) after 5, 10 and 13 days respectively. Outtar, et al. (2011) tested some biological agents on the locust pilgrim, S. gregaria, and the Moroccan locust, Dociostaurus maroccanus they found that Azadirachta Indica, the Neem and Lawsonia inermis, the henna gave good control. Teflubenzuron and Triflumuron have an important bio-insecticide action and prevent the molt in the insects leading to their death.

Table (2): Combined effect of the fungus, $M$. anisopliae var. acridum and $20 \%$ of recommended dose of some affecting treatments against nymphs of the African locust, L. migratoria migratorioides in the field.

\begin{tabular}{|c|c|c|c|c|c|c|c|c|c|c|c|c|c|c|c|c|c|c|c|c|c|c|c|c|}
\hline days & & & n & & & & & & & p & enta & $\begin{array}{l}\text { ges } \\
\text { ods }\end{array}$ & s aft & $\begin{array}{l}\text { er th } \\
\text { days }\end{array}$ & e ir & ndi & & & & & tre & & tme & ent \\
\hline Treat. & 1 & 2 & 3 & 4 & 5 & 6 & 7 & 8 & 9 & 10 & 11 & 12 & 13 & 14 & 15 & 16 & 17 & 18 & $3 \mid 1$ & $9 \mid 2$ & $0 \mid 2$ & 12 & $\left.22\right|_{K} ^{T}$ & $\begin{array}{l}\text { Total } \\
\text { Kill\% }\end{array}$ \\
\hline Control & 0 & 0 & 0 & 0 & 0 & 0 & 0 & 0 & 0 & 0 & 0 & 0 & 0 & 0 & 0 & 0 & 0 & 0 & c & 0 & 0 & $0 \mid 0$ & 0 & \\
\hline $\begin{array}{l}\text { Fungus } 25 \mathrm{~g} / \text { ha. }+ \\
\text { anti-feeding } 20 \%\end{array}$ & 4 & 5 & 6 & 12 & 20 & 40 & 45 & 55 & 70 & 80 & 85 & 95 & 100 & & & & & & & & & & & \\
\hline $\begin{array}{l}\text { Fungus } 25 \mathrm{~g} / \text { ha. }+ \\
\text { cascade } 20 \%\end{array}$ & 5 & 6 & 6 & 10 & 15 & 30 & 44 & 50 & 65 & 75 & 90 & 95 & 100 & & & & & & & & & & & \\
\hline $\begin{array}{l}\text { Fungus } 25 \mathrm{~g} / \text { ha. }+ \\
\text { Admiral20\% }\end{array}$ & 6 & 8 & 9 & 12 & 19 & 36 & 45 & 51 & 66 & 80 & 89 & 96 & 99 & 100 & & & & & & & & & & \\
\hline $\begin{array}{l}\text { Fungus } 25 \mathrm{~g} / \text { ha. }+ \\
\text { pestban } 20 \%\end{array}$ & 11 & 12 & 14 & 16 & 50 & 60 & 75 & 80 & 90 & 95 & 100 & & & & & & & & & & & & & \\
\hline $\begin{array}{l}\begin{array}{l}\text { Fungus } 25 \mathrm{~g} / \mathrm{ha} .+ \\
\text { chloropyrifos } 20 \%\end{array} \\
\end{array}$ & 13 & 15 & 19 & 25 & 55 & 70 & 80 & 85 & 92 & 98 & 100 & & & & & & & & & & & & & \\
\hline
\end{tabular}

The mortality percentages caused by the fungus with $20 \%$ of the recommended dose of pestban $48 \%$ E.C. and Chloropyrifos $45 \%$ U.L.V. were (50 and 100) and (70 and 100\%) after 5 and 11 days respectively. AbdelFattah (2005) studied the combined effects of the fungus, M. anisopliae var. acridum isolate IMI 330189 with sub-lethal dose of some insecticides on the desert locust, $S$. gregaria in Eastern desert of Egypt. He reported that all insecticides were not toxic to the fungus and did not inhibit its effect on locust. In conclusion, the fungus alone induced moderate percentages of reduction 
in the population of this pest after 10 days post treatment. While the integration between $M$. anisopliae and $20 \%$ of the recommended dose of antifeeding agent, Flufenoxuron, pyripoxyfen and Chloropyrifos exhibited the highest integral action, recorded $100 \%$ mortality after $11-13$ days of application post treatment. Also, on comparing the dose and half the dose of the fungus the full dose gave the same trend nearly. So it is preferable using half the dose for saving costs. It is worth mentioning that the integral action lead to decrease the period of complete action of the fungus. May be due to weaken the insects.

\section{REFERENCES}

Abdel-Fattah, T.A.(2005). The combined effects of the entomopathogenic fungus Metarhizium anisopliae var acridium IMI 330189(Green Muscle) and the sub-lethal doses of some insecticides on the desert locust, Schistocerca gregaria (Forskal.). Egypt. J. Agric Res., 83(2) 551-561.

Abdel-Fattah, T. A.; Mohamed, G. A. and Abdel-Latife, G.M. (2012). Integral action of metarhizium anisopliae, nosema locustae and chlorfluazurone against the berseem grasshopper, Euprepocnemis plorans plorans (charp.) in the field. Zagazig J. of Agric. Res., 39 (3) $511-516$.

Al-Fifi, Z. I. A. (2009). Effect of different Neem products on the mortality and fitness of adult Schistocerca gregaria (Forskal). Journal of King Abdulaziz University Science, 21(2): 299-315.

Arthurs, S. , and Thomas M. B. (2000). Effects of a mycoinsecticide on feeding and fecundity of the Brown Locust Locustana pardalina. Biocontr. Sci. Technol. 10, 321-329.

El-Gammal A.M; HM. El-Gawhary; Abd El-Fattah T.A. and M.T. Mohammed., (2004). Field trials to investigate the spores of Metarhizium flavoviride as microbial control agent and its Integrated action with some insect growth regulators against Locusta migratoria migratorioides in Shark El-Uwainat area .Egypt . J. Appl. Sci., 19: 255-265.

Gesraha, M. A. (2007). Impact of entomopathogenic fungi on the desert locust, Schistocerca gregaria (Forskal). Egypt. J. Biol. Pest Control, 17 (1/2): 83-89.

Ghazawy, N. A.; Awad, H.H. and Rahman, M. A. (2010). Effects of Azadirachtin on embryological development of the desert locust, Schistocerca gregaria (Forskal). J.of Orthoptera Res., 19(2): 327-332.

Goettel, M. S.; Poprowski, T. J.; Vandeberg, J. D. and Roberts, P. W. (1995). Safety to non target in vertebrates of fungal biocontrol agents. In: Laird. M., Lacey, L. A. and Davids on, E.W (eds.), Safety of microbial insecticides. CRC press, Boca Raton. Pp. 209-231.

Hosny, A. K.; Agamy, E. A.; Taha,G. Z. and El-Husseini, M. M. (2009). Efficacy of the Fungus, Metarhizium anisopliae var. acridum against some acridid insects. Egyptian Journal of Biological Pest Cotrol, 19(2): 135-141. 
Lomer C.J. (1997). Metarhizium flavoviride: recent results in the control of locusts and grasshoppers. In Krall S., R. Peveling and D. Ba Diallo (eds.) New Strategies in Locust Control. Birkhäuser $t$ Verlag, Basel, Switzerland, pp. 415-424.

Outer, F.; Doumandji-Mitiche, B.; Mouhouche, F. And Doumandji, S. (2011). Alternative method against locusts. 4eme conference Internationale surles methods Alternatives en protection des cuttures. Evolution des cadres reglementairs europeen et francais. Nouveaux moyens et strategies Innovates, Nouveau siecle, Lille, France 8-10 mars 2011. 197-204.

Sas (1995). Statistical analysis system stat user's guide, release 6.03. ed., SAS Institute Inc., Cary, Nc. USA, pp. 125-154.

Prior, C. J. and Greathead, D. J. (1989). Biological control of locusts: the potential for the exploitation of pathogens. FAO Plant Protection Bullent, 37: 37-48.

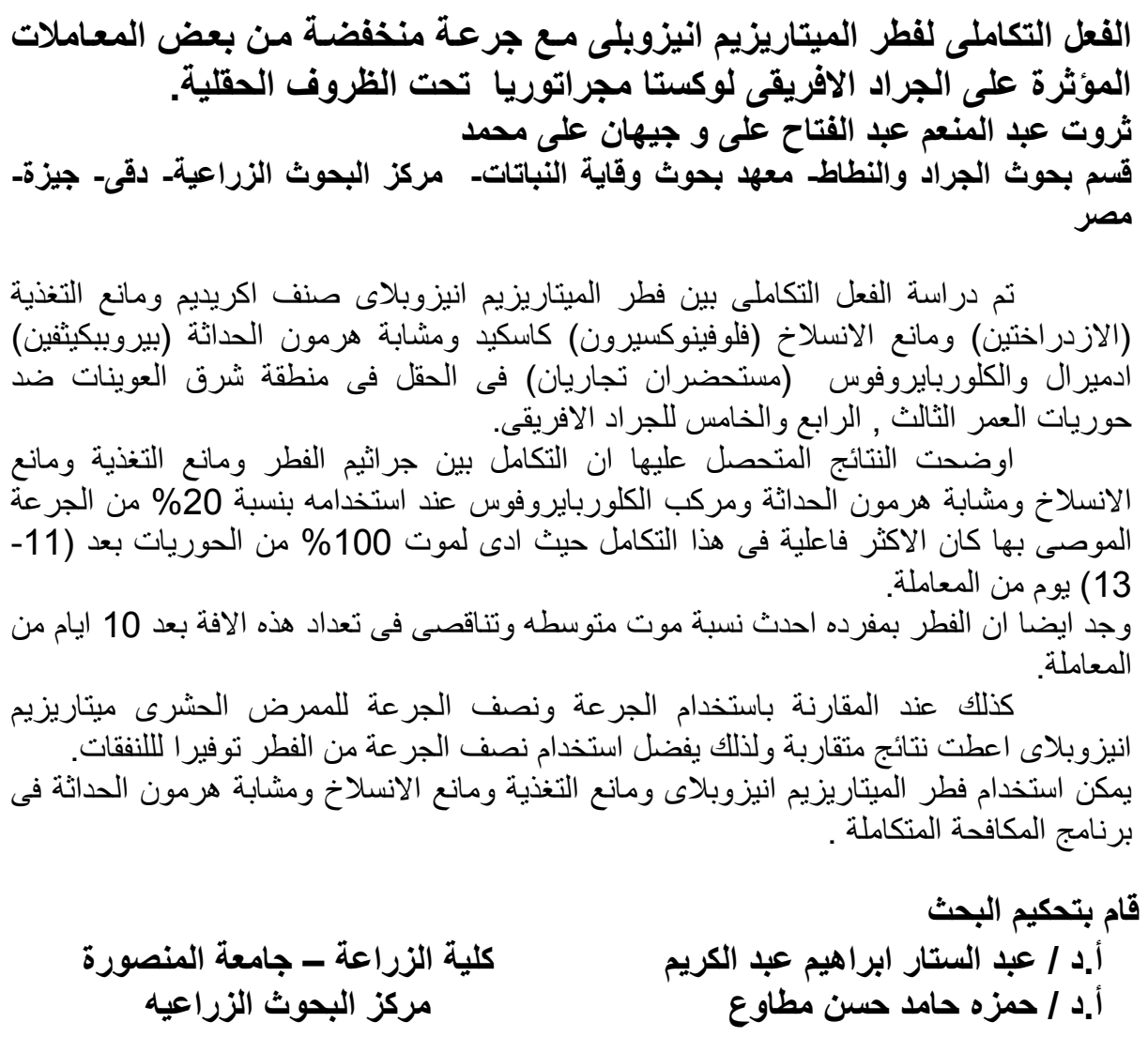

